\title{
Beyond catalyst deactivation: cross-metathesis involving olefins containing $\mathbf{N}$-heteroaromatics
}

\author{
Kevin Lafaye, Cyril Bosset, Lionel Nicolas, Amandine Guérinot ${ }^{*}$ and Janine Cossy*
}

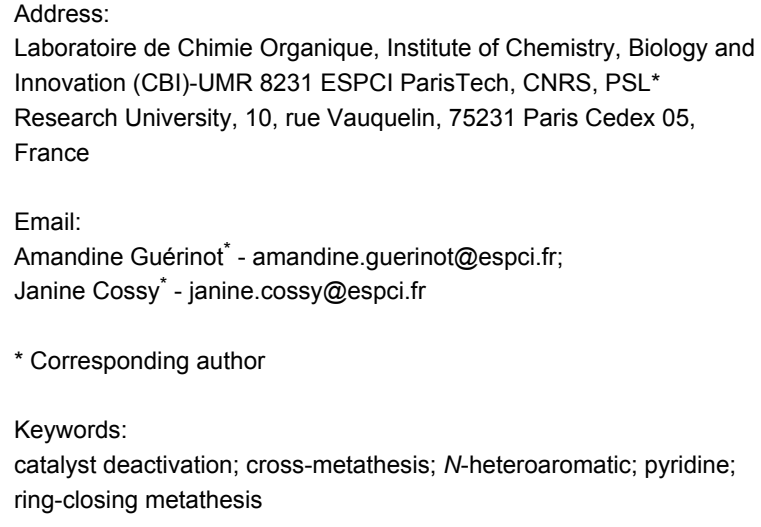

Beilstein J. Org. Chem. 2015, 11, 2223-2241.

doi:10.3762/bjoc. 11.241

Received: 17 July 2015

Accepted: 20 October 2015

Published: 18 November 2015

This article is part of the Thematic Series "Progress in metathesis chemistry II".

Guest Editor: K. Grela

(c) 2015 Lafaye et al; licensee Beilstein-Institut. License and terms: see end of document.

\begin{abstract}
Alkenes containing $N$-heteroaromatics are known to be poor partners in cross-metathesis reactions, probably due to catalyst deactivation caused by the presence of a nitrogen atom. However, some examples of ring-closing and cross-metathesis involving alkenes that incorporate $N$-heteroaromatics can be found in the literature. In addition, recent mechanistic studies have focused on the rationalization of nitrogen-induced catalysts deactivation. The purpose of this mini-review is to give a brief overview of successful metathesis reactions involving olefins containing $N$-heteroaromatics in order to delineate some guidelines for the use of these challenging substrates in metathesis reactions.
\end{abstract}

\section{Introduction}

Over the past decades, metathesis has become a key reaction within the organic chemist's toolbox [1-6]. Since its infancy in the 50's, metathesis has grown in importance and, today, applications in a broad variety of areas such as natural product synthesis [7-11], polymerization [12], drug discovery [7], petrochemistry or agricultural chemistry have been reported. One of the reasons of this success is the discovery of well-defined, stable, highly chemoselective and now commercially available catalysts particularly the Grubbs catalysts $1^{\text {st }}$ and $2^{\text {nd }}$ generation (GI and GII) and the Grubbs-Hoveyda II catalyst (G-HII) (Figure 1) [13].
A large array of functional groups including alcohols, halides, esters, amides, carbamates and sulfonamides are compatible with the metathesis conditions [14-20]. However, the involvement of alkenes containing a nitrogen atom such as an amine or an $N$-heteroaromatic ring in metathesis reactions is still problematic and have been the subject of several research works [21-26]. Lewis basic and nucleophilic amines are supposed to interfere with the catalyst and/or intermediates, thus disrupting the catalytic cycle and preventing the process to occur (vide infra). Various approaches have been explored to allow the use of primary and secondary amines in ring-closing metathesis 


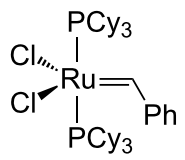

GI

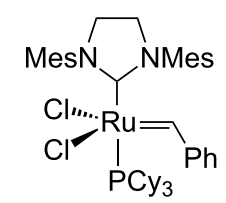

GII

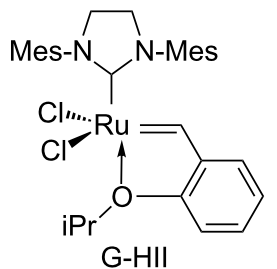

G-HII

Figure 1: Some ruthenium catalysts for metathesis reactions.

(RCM) and cross-metathesis (CM), and one of them is the transformation of amines into carbamates, amides or sulfonamides [27-29]. As an alternative, metathesis reactions can be performed with olefins possessing ammonium salts that can be formed from the corresponding amines either in a preliminary step or in situ, in the presence of an acidic additive [30-35]. In addition, Lewis acids in catalytic amounts were shown to enhance the reactivity of amino compounds in metathesis reactions [36,37]. Involvement of $N$-heteroaromatics containing olefins in metathesis has been less documented. In this review, we would like to give an overview of successful metatheses involving alkenes that possess $N$-heteroaromatics in order to delineate some guidelines. Some mechanistic insights dealing with catalyst deactivation caused by amino derivatives will be first presented and discussed. RCM and CM involving alkenes possessing $N$-heteroaromatics will be then successively examined [38].

\section{Review}

\section{Mechanistic insights into amine-induced catalyst deactivation}

Recently, intensive studies dealing with ruthenium catalyst deactivation in metathesis have been published, most of them focusing on the GII catalyst [39-43]. In 2007, Grubbs et al examined the decomposition pathways of various ruthenium methylidenes using NMR spectroscopy [44]. The methylidenes $\mathbf{1}$ and $\mathbf{2}$ derived from GI and GII had a half-life of $40 \mathrm{~min}$ and $5 \mathrm{~h} 40 \mathrm{~min}$, respectively at $55{ }^{\circ} \mathrm{C}$ and the main byproduct $\mathrm{CH}_{3} \mathrm{PCy}_{3}{ }^{+} \mathrm{Cl}^{-}$was identified using ${ }^{1} \mathrm{H},{ }^{13} \mathrm{C}$ and ${ }^{31} \mathrm{P}$ NMR data as well as HRMS data. The deactivation of the catalysts was hypothesized to go through ligand dissociation from $\mathbf{1}$ and $\mathbf{2}$ followed by a nucleophilic attack of the free phosphine on the methylidene intermediates 3 and $\mathbf{4}$ to give $\mathrm{CH}_{3} \mathrm{PCy}_{3}{ }^{+} \mathrm{Cl}^{-}$and inactive ruthenium complexes. Similar observations were made in the absence or in the presence of ethylene in the reaction medium (Scheme 1).

Similar studies concerning the Grubbs-Hoveyda II catalyst were difficult due to the instability of the methylidene derivative that could not be isolated. Thus, the decomposition of G-HII was studied in the presence of ethylene and unidentified ruthenium hydride species were observed by ${ }^{1} \mathrm{H}$ NMR after $24 \mathrm{~h}$. This result indicates that another mode of deactivation that does not involve a phosphine is involved in G-HII degradation (Scheme 2).

In 2009, Moore et al. studied the stability of GI and GII in the presence of $n$-butylamine using ${ }^{1} \mathrm{H}$ and ${ }^{31} \mathrm{P}$ NMR spectroscopy [39]. While GI decomposed within 10 min after formation of bisamino complex 7 (Scheme 3, reaction 1), GII resulted in a

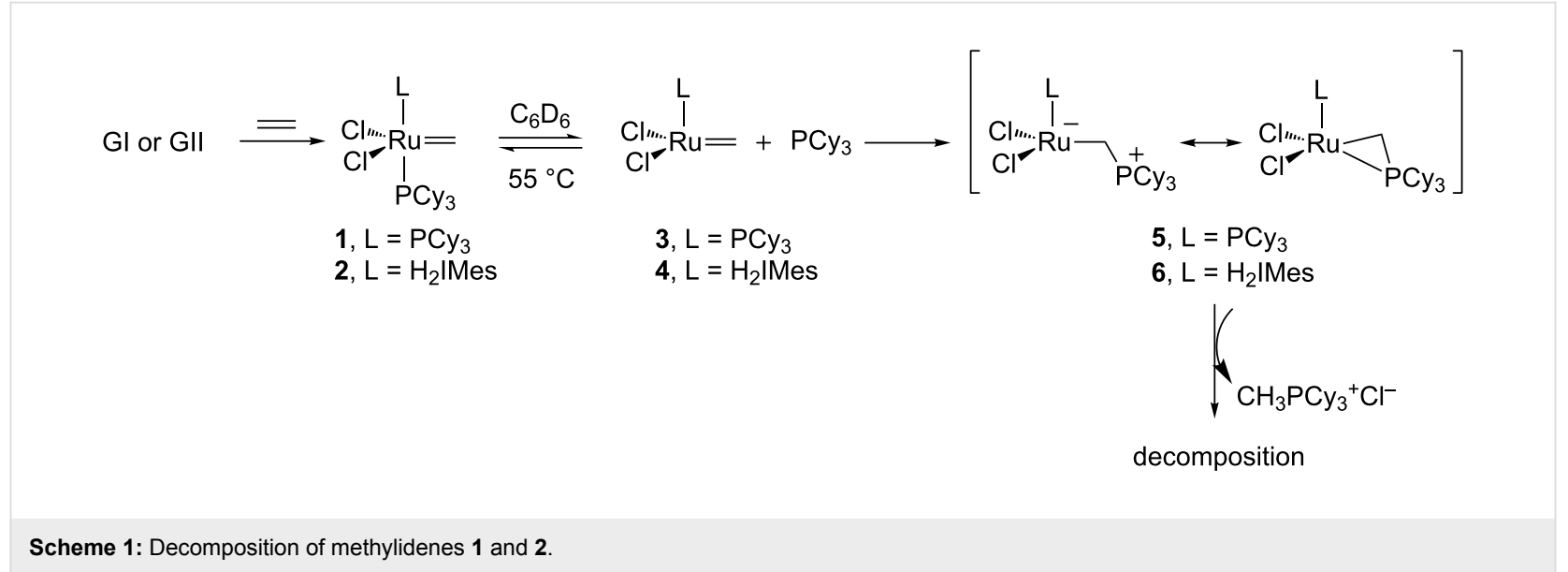




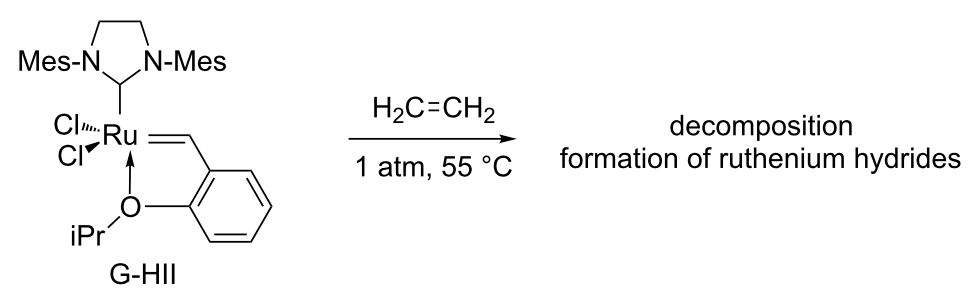

Scheme 2: Deactivation of G-HII in the presence of ethylene.

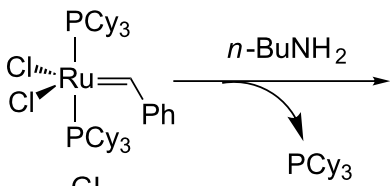

Gl

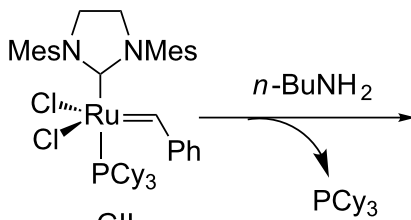

Gll

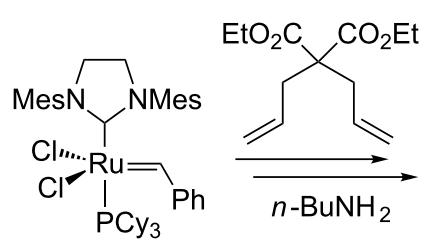

GII

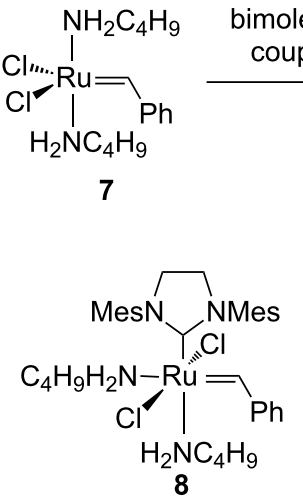
coupling<smiles>[3H]/C=C/c1ccccc1</smiles>

[Ru] species

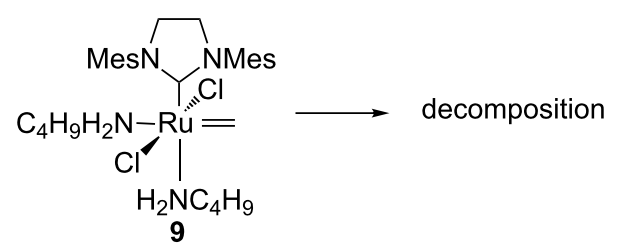

Scheme 3: Reaction between GI/GII and $n-\mathrm{BuNH}_{2}$

new stable bis-amino ruthenium complex 8 that was isolated and characterized using X-ray diffraction (Scheme 3, reaction 2). In both cases, free $\mathrm{PCy}_{3}$ was observed by NMR confirming amine-induced phosphine displacement. The decomposition of GI was hypothesized to go through a bimolecular coupling from 7. On the contrary, the bulky NHC ligand present in $\mathbf{8}$ could prevent this side reaction. However, in the presence of diethyl diallylmalonate and $n$-butylamine, GII decomposed readily probably due to an increased instability of the less hindered methylidene 9 compared to benzylidene 8 (Scheme 3, reaction 3 ).

Fogg et al. completed this study by focusing on aminemediated degradation of GII and they highlighted various plausible decomposition pathways depending on the nature of the amine [45]. At first, the reaction between GII and various amines such as $n$-butylamine (a), pyrrolidine (b), morpholine (c) and DBU (d) were examined by ${ }^{1} \mathrm{H}$ NMR. As already highlighted by Moore et al., in the presence of $n$-butylamine, GII was transformed into $\mathbf{8}$ and the latter slowly decomposed (halflife $=3.5 \mathrm{~h}$ ) to give ruthenium species and amine $\mathbf{1 0}$ as the major identified organic compound. This amine would come from the attack of the non-bulky $n$-butylamine on the hindered benzylidene. With more sterically hindered amines $\mathbf{b}-\mathbf{d}$, the ruthenium complexes $\mathbf{1 1 b}-\mathbf{d}$, resulting from phosphine displacement, proved to be stable even after $24 \mathrm{~h}$ at $60{ }^{\circ} \mathrm{C}$ (Scheme 4).

The half-life of methylidene $\mathbf{2}$ derived from GII in the presence of the amines were then evaluated using NMR experiments [45]. The steric hindrance of the amine appeared to be a critical parameter. The non-bulky primary amine $n$-butylamine (a) induced a fast decomposition of the methylidene 2 (Table 1, entry 1) whereas secondary amines such as pyrrolidine (b) and morpholine (c) are less detrimental to the catalyst (Table 1, entries 2 and 3). Interestingly the $\mathrm{sp}^{2}$ amine DBU did not induce any decomposition of the methylidene intermediate (Table 1 , entry 4 ). 


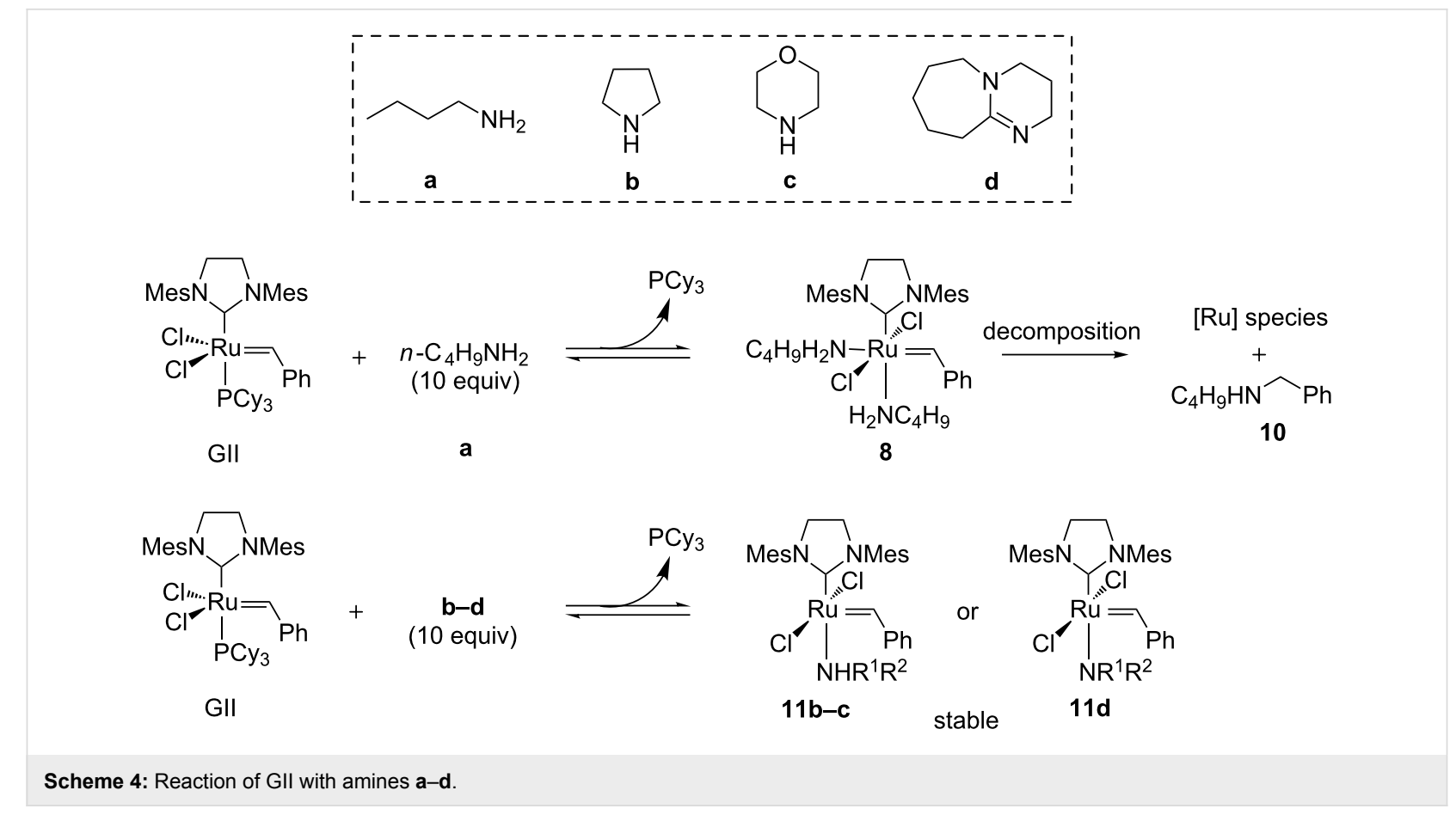

Table 1: Decomposition of methylidene 2 in the presence of amines a-d.

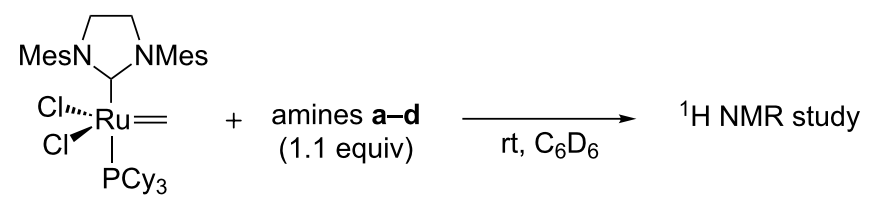

2

\begin{tabular}{ccc}
\hline Entry & Amine & Half-life \\
\hline 1 & $n-\mathrm{C}_{4} \mathrm{H}_{9} \mathrm{NH}_{2}(\mathbf{a})$ & $12 \mathrm{~min}$ \\
2 & pyrrolidine $(\mathbf{b})$ & $1.5 \mathrm{~h}$ \\
3 & morpholine $(\mathbf{c})$ & $14 \mathrm{~h}$ \\
4 & $\mathrm{DBU}(\mathbf{d})$ & $\mathbf{\mathrm { h }}$
\end{tabular}

In all decomposition cases, the main identified product was the phosphonium $\mathrm{CH}_{3} \mathrm{PCy}_{3}{ }^{+} \mathrm{Cl}^{-}$that would result from a nucleophile attack of the free $\mathrm{PCy}_{3}$ liberated through ligand exchange on the methylidene 2 (Scheme 5).
To complete their study, the authors examined the influence of the amines on the GII-catalyzed RCM of diene 13 [45]. In the presence of amines a-c, decomposition was observed and $\mathrm{CH}_{3} \mathrm{PCy}_{3}{ }^{+} \mathrm{Cl}^{-}$was generated. Interestingly, in the presence of

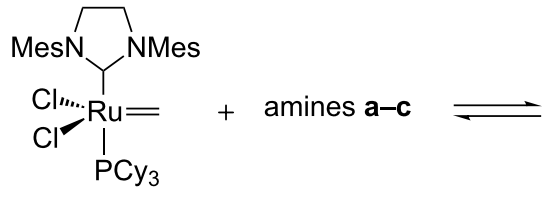

2

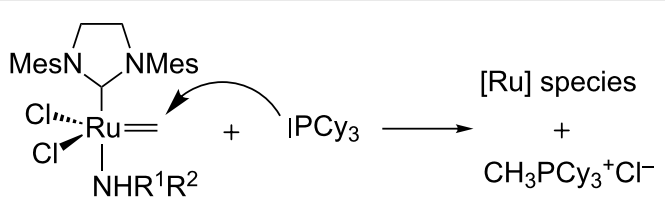

$12 a-c$

Scheme 5: Amine-induced decomposition of GII methylidene 2. 
DBU, fast decomposition of the catalyst was noticed and only the presence of free $\mathrm{PCy}_{3}$ could be observed. According to the previous experiments, DBU was not able to decompose the methylidene resting-state and, consequently, a deprotonation of the metallacyclobutane 15 was hypothesized (Scheme 6).

The influence of pyridine as an additive on the deactivation of the metathesis catalyst has not been yet studied in detail [44]. When reacted with an excess of pyridine, the methylidene adduct 2 obtained from GII led to the formation of inactive complex 16 together with $\mathrm{CH}_{3} \mathrm{PCy}_{3}{ }^{+} \mathrm{Cl}^{-}$. These products would result from a ligand exchange followed by a nucleophilic attack of $\mathrm{PCy}_{3}$ on the methylidene intermediate (Scheme 7).

Very recently, the amine-induced deactivation of G-HII catalyst was studied by Fogg et al. [46]. When G-HII was treated with an excess of various amines a-e (10 equiv), comparable results with those obtained with GII were obtained. In the presence of a non-bulky primary amine such as $n$-butylamine, the bis-aminobenzylidene 17 was formed and complete decomposition was noticed after $12 \mathrm{~h}$ at rt yielding ruthenium complex 18 and amine 10. In the presence of secondary amines $\mathbf{b}$ and $\mathbf{c}$ and $\mathrm{sp}^{2}$ amine $\mathbf{d}$, ruthenium complexes $\mathbf{1 9 b}-\mathbf{d}$ possessing one amine were formed and proved to be thermally stable. When the G-HII catalyst was treated with pyridine (e), the stable bis-pyridyl adduct 20e was formed in equilibrium with G-HII and no significant decomposition of the catalyst was observed (Scheme 8).

In contrast, the addition of amino additives such as pyridine, morpholine, $\mathrm{Et}_{3} \mathrm{~N}$ or DBU was shown to be detrimental to the G-HII-catalyzed dimerization of styrene (Table 2). Moderate to

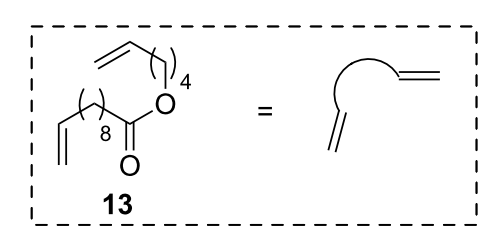

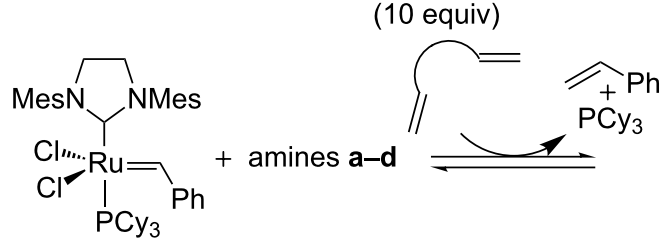

GII<smiles></smiles>

amines a-c $\mid$,

[Ru] species decomposition

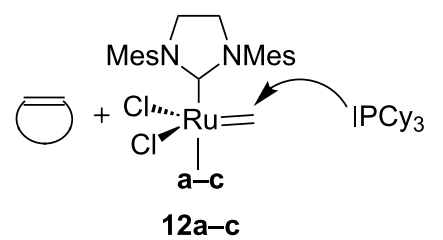

Scheme 6: Amine-induced decomposition of GII in RCM conditions.

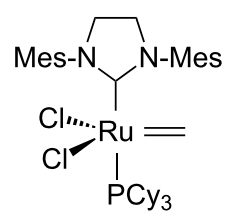

2<smiles>C=C1C=CC=CCC1</smiles><smiles></smiles>

16 


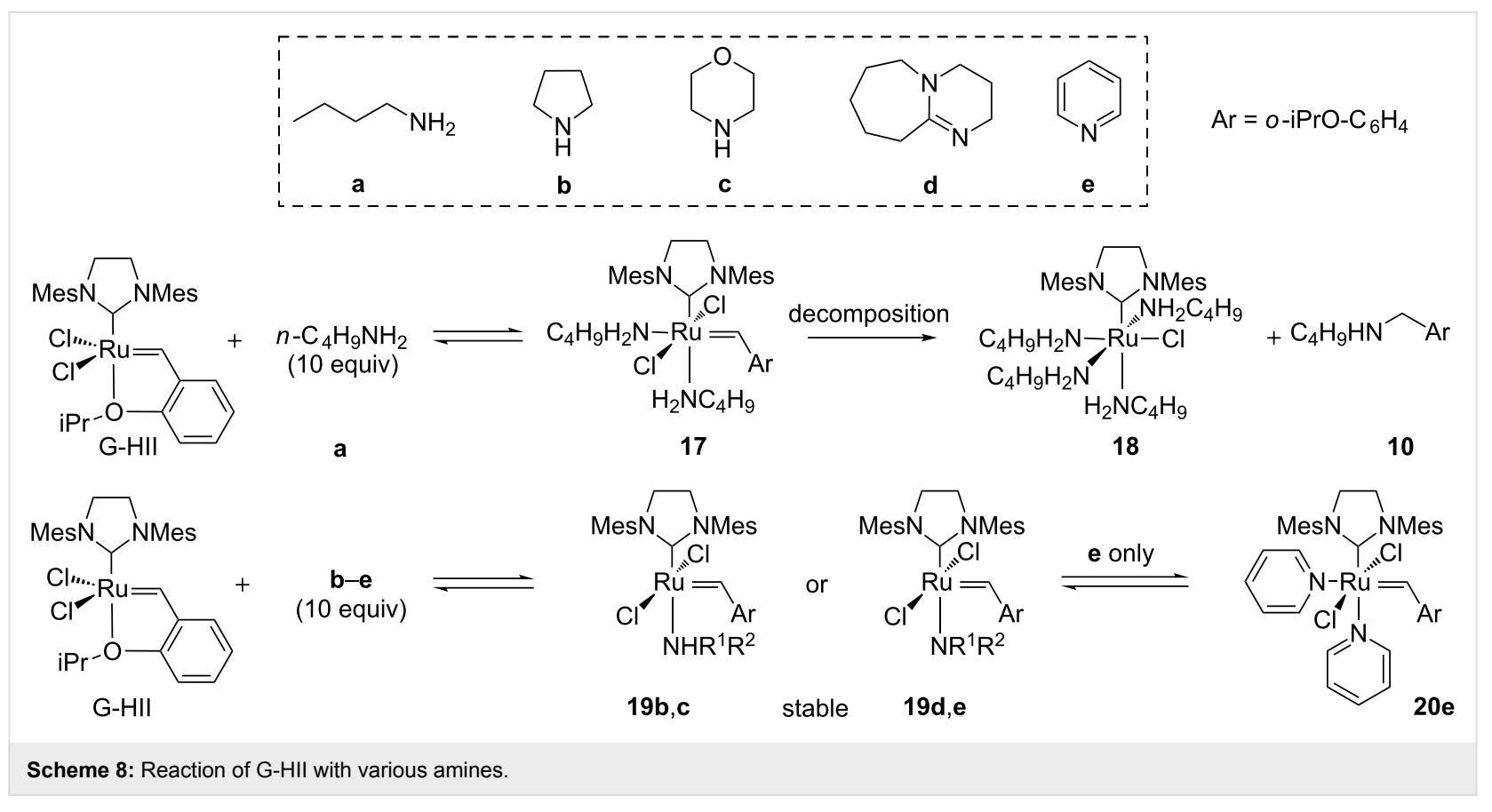

poor yields in stilbene 7 ' were obtained and the value of the yields was correlated with the $\mathrm{p} K_{\mathrm{a}}$ of the couple ammonium/ amine. An increased Brønsted basicity of the amine seemed to induce a faster deactivation of the catalyst.

\begin{tabular}{|c|c|c|c|}
\hline 21 & $\frac{\begin{array}{r}\mathrm{G}-\mathrm{H} \\
\text { additi }\end{array}}{60}$ & & $7^{\prime}$ \\
\hline Entry & Additive & $p K_{a}^{a}$ & Yield \\
\hline 1 & none & - & $94 \%$ \\
\hline 2 & pyridine & 12.6 & $45 \%$ \\
\hline 3 & morpholine & 16.6 & $18 \%$ \\
\hline 4 & $\mathrm{Et}_{3} \mathrm{~N}$ & 18.5 & $9 \%$ \\
\hline 5 & pyrrolidine & 19.6 & $<5 \%$ \\
\hline 6 & DBU & 24.1 & $<5 \%$ \\
\hline
\end{tabular}

${ }^{a} \mathrm{pK} a$ of the conjugate acid in $\mathrm{CH}_{3} \mathrm{CN}$.
In addition, when the self-metathesis of styrene was performed in the presence of pyrrolidine, $\mathrm{DBU}$ or $\mathrm{Et}_{3} \mathrm{~N}$, olefin 22 was formed as the major product (Scheme 9).

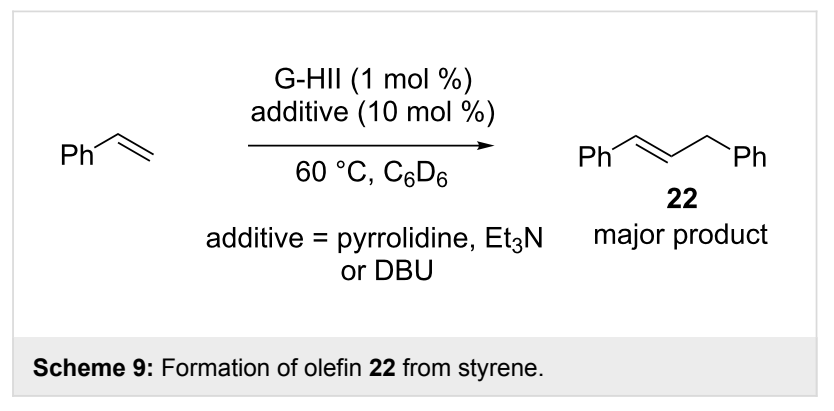

To explain these observations, a deactivation mechanism involving a deprotonation of the metallacyclobutane intermediate $\mathbf{2 3}$ was hypothesized. The resulting anionic ruthenium complex 24 would be protonated and, after elimination, alkene 22 and unidentified ruthenium complexes would be produced (Scheme 10).

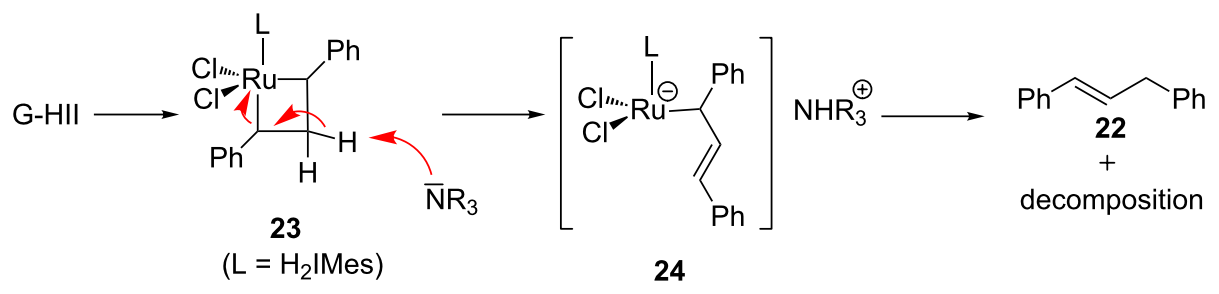

Scheme 10: Hypothetic deactivation pathway of G-HII. 
According to these mechanistic investigations, several pathways are involved in the amine-induced catalyst decomposition depending on the nature of the amine and of the ruthenium complex. Non-bulky primary amines can attack directly benzylidene species and are responsible for the fast degradation of the catalyst. In the case of a phosphine-containing catalyst such as GII, secondary amines exchange with $\mathrm{PCy}_{3}$ and the free phosphine can perform a nucleophilic attack on the methylidene intermediate triggering its decomposition. In contrast, $\mathrm{sp}^{2}$ amines such as DBU seem rather to react with the metallacyclobutane intermediate. In the case of G-HII catalyst, a deprotonation of the metallacyclobutane is hypothesized to explain the amine-induced decomposition (Table 3). Consequently, a modulation of the Brønsted basicity and/or the nucleophilicity of the amine/ $N$-heteroaromatic present on an alkene may allow its use in metathesis reactions.

\section{Ring-closing metathesis \\ Formation of pyridinium/imidazolium salt prior to metathesis}

Most of the examples of RCM involving substrates that possess a pyridine ring relied on the pre-requisite formation of a pyridinium salt. In 2004, Vaquero et al. reported the synthesis of dihydroquinolizium cations through RCM of dienic pyridinium salts in the presence of the GII catalyst (Scheme 11) [47]. The formation of seven- and eight-membered rings required high dilution. Few years later, the same authors showed that it was possible to oxidize 3,4-dihydroquinolizinium salts into their quinolizinium counterparts using $\mathrm{Pd} / \mathrm{C}$ at high temperature (Scheme 11) [48].
This method was used to prepare polycyclic scaffolds that can be encountered in diverse alkaloid natural products such as coralyne and berberine (Scheme 12) [49].<smiles></smiles>

28

\section{$\frac{\mathrm{G}-\mathrm{HII}(5-15 \mathrm{~mol} \%)}{\left(\mathrm{CH}_{2}\right)_{2} \mathrm{Cl}_{2} \text { or }(\mathrm{CH})_{2} \mathrm{Cl}_{2}}$ $\mathrm{c}=0.05 \mathrm{M}$} $35-83 \%$<smiles>[R][X]1ccc[R]([O-])c1</smiles>

29<smiles>COC1=Cc2cc[n+](C)c(C)c2C=c2cc(OC)c(OC)cc2=C1</smiles><smiles></smiles>

berberine

Scheme 12: Synthesis of polycyclic scaffolds using RCM.

Similarly, enyne ring-closing metathesis reactions were performed to access a variety of vinyl-3,4-dihydroquinolizinium salts (Scheme 13) [50].

In their synthetic approach towards $(R)-(+)$-muscopyridine, Fürstner and Leitner have constructed the 13-membered ring macrocycle using a RCM applied to diene 34 [51]. In order to avoid the catalyst deactivation due to the presence of the pyridine moiety, the precursor $\mathbf{3 4}$ was first treated with $\mathrm{HCl}$ to form

Table 3: Amine-induced degradation pathways of GII and G-HII.

\begin{tabular}{|c|c|c|}
\hline & GII & G-HII \\
\hline Primary amine & $\begin{array}{l}\text { Nucleophilic attack on the benzylidene and/or } \\
\text { methylidene } 2\end{array}$ & $\begin{array}{l}\text { Nucleophilic attack on the benzylidene and/or } \\
\text { methylidene }\end{array}$ \\
\hline Secondary amine & $\begin{array}{l}\text { Ligand exchange and nucleophilic attack of free } \\
\mathrm{PCy}_{3} \text { on the methylidene } 2\end{array}$ & Deprotonation of the metallacyclobutane $\mathbf{2 3}$ \\
\hline $\mathrm{sp}^{2}$ amine & $\begin{array}{l}\text { Nucleophilic attack and/or deprotonation of the } \\
\text { metallacyclobutane } 15\end{array}$ & Deprotonation of the metallacyclobutane $\mathbf{2 3}$ \\
\hline
\end{tabular}<smiles>[R]c1cc[n+]2c(c1)C=CC(C=C)C2</smiles>
$\mathrm{TfO}^{-}$

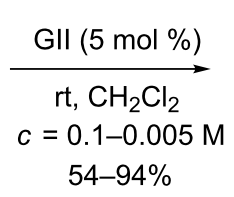

25

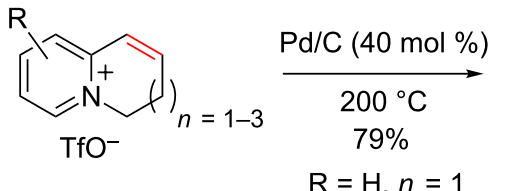

26<smiles>O=C(O)c1cccc2cccc[n+]12</smiles>

27 
<smiles>[R]C#CCC[n+]1c([O-])cccc1C=C</smiles>

GII (5 mol \%)

$$
\mathrm{CH}_{2}=\mathrm{CH}_{2}
$$

$80^{\circ} \mathrm{C},\left(\mathrm{CH}_{2}\right)_{2} \mathrm{Cl}_{2}$

$c=0.001 \mathrm{M}$<smiles></smiles>

31<smiles>[R]C#Cc1cccc[n+]1CCC([R])=C</smiles><smiles>[R]C(=C)C1=C([R])CC[n+]2c([R])cccc21</smiles>

33

Scheme 13: Enyne ring-closing metathesis.

the corresponding hydrochloride salt which was then reacted with the ruthenium catalyst $\mathbf{3 6}$ under diluted conditions to deliver 35. After reduction of the double bond, the targeted $(R)$ $(+)$-muscopyridine was isolated (Scheme 14).

A similar strategy was used in the synthesis of the tris-pyrrole macrocyclic pigment nonylprodigiosin [52]. A preliminary protonation of the tris-pyrrole followed by a RCM applied to $\mathbf{3 7}$ in the presence of the ruthenium catalyst $\mathbf{3 6}$ gave the macrocycle 38, which was then transformed into the saturated derivative 39 using the Wilkinson's catalyst (Scheme 15).

The use of an acidic additive also allowed the synthesis of fused bicyclic imidazoles through a GII-catalyzed RCM reaction (Scheme 16) [53].

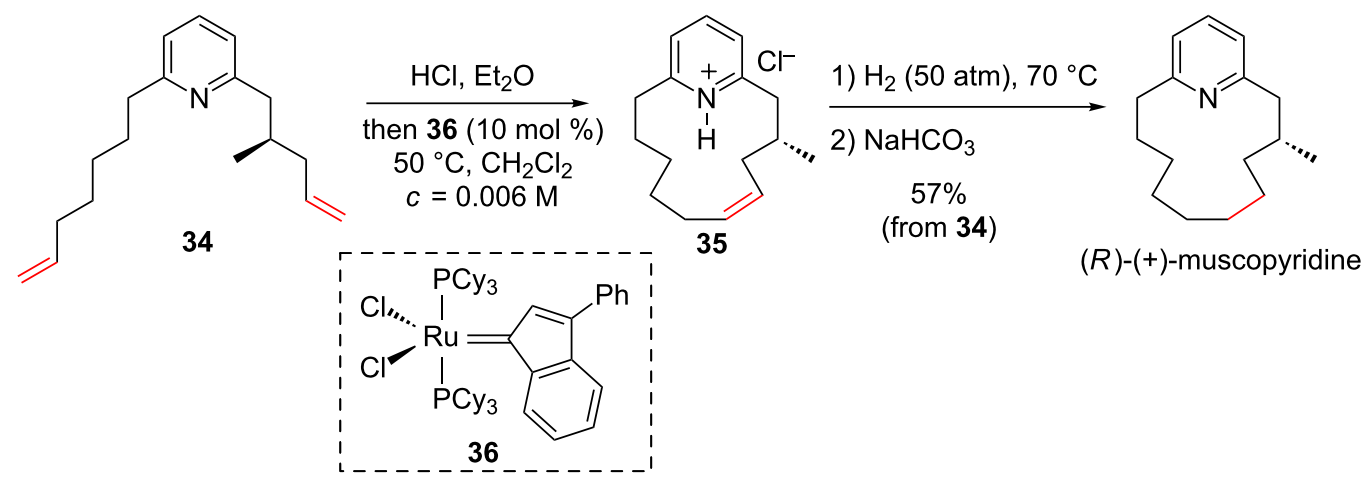

Scheme 14: Synthesis of $(R)-(+)-$ muscopyridine using a RCM strategy<smiles>C=CCCCCc1ccc(-c2cc(OC)c(C=C3C=CC(Cl)=[NH+]3)[nH]2)[nH]1</smiles>

37

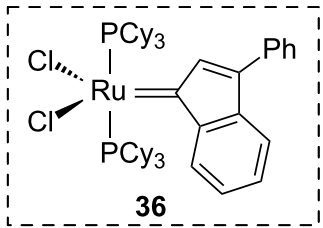

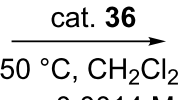

$c=0.0014 \mathrm{M}$

$65 \%$

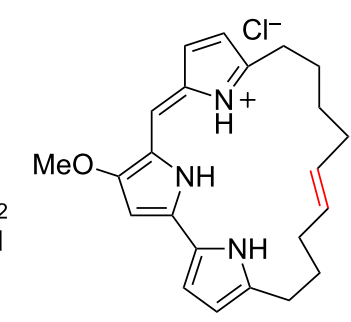

38

$\mathrm{RhCl}\left(\mathrm{PPh}_{3}\right)_{3}$ (cat.) $\quad 90 \%$ $\mathrm{H}_{2}$ (1 atm)

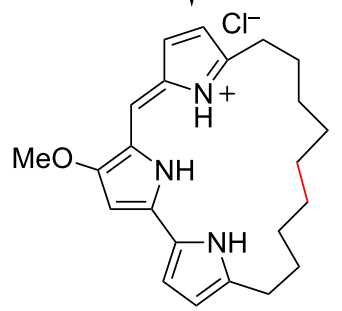

39

nonylprodigiosin $\cdot \mathrm{HCl}$ 
<smiles>C=CCc1nc[nH]c1CC=C</smiles>

40

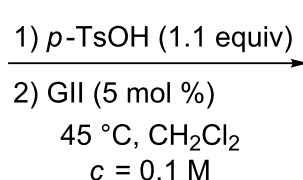

$87 \%$

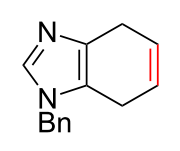

41
Scheme 16: Synthesis of a bicyclic imidazole.

Only few examples of RCM involving dienes that contain $N$-heteroaromatics were described on non-protonated species. In 2001, in the course of their studies towards ergot alkaloids synthesis, Martin and co-workers used a RCM to form the tetracyclic compound $\mathbf{4 3}$ incorporating an indole moiety. A poor yield was obtained in the presence of the GI catalyst and the more reactive Schrock complex $\mathbf{4 4}$ had to be used instead. Worthy of note, the indole was protected as a tosylamide and the GI deactivation may be caused by the tertiary amine (Scheme 17) [54,55].

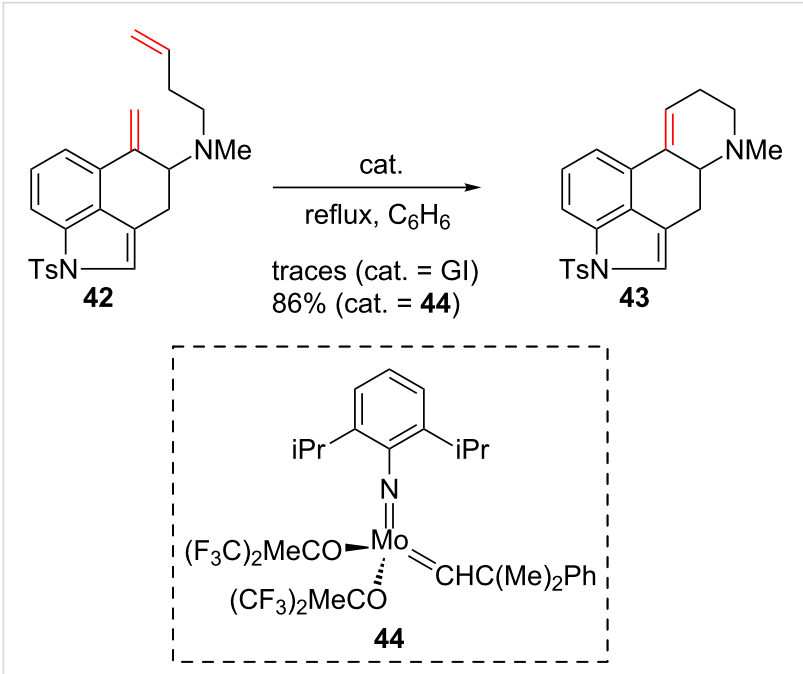

Scheme 17: RCM using Schrock's catalyst 44.

It should be noted that $N$-heteroaromatics substituted either by bulky or electron-withdrawing groups are involved. In 2004 ,
Billing and co-workers employed a RCM strategy to construct 1,6-pyrido-diazocine 46 with an excellent yield of $94 \%$ (Scheme 18) [56]. The presence of the two sulfonamide substituents on the pyridyl ring might decrease the basicity of the nitrogen atom thus allowing the metathesis to proceed. Steric hindrance due to the $\mathrm{C} 2$ substitution may also prevent the pyridine-induced catalyst deactivation.

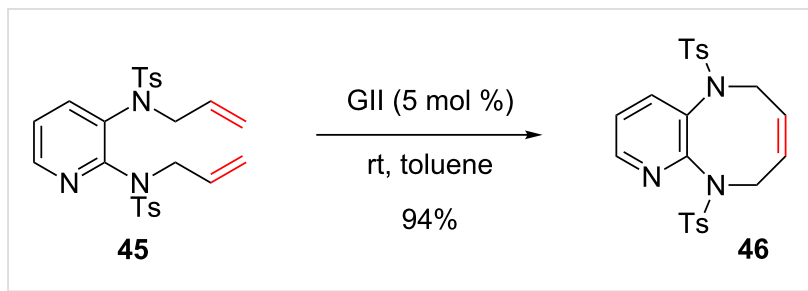

Scheme 18: Synthesis of 1,6-pyrido-diazocine 46 by using a RCM.

Grimaud et al. described the formation of fused pyrimidoazepines from bisallylic substrates using a G-HII-catalyzed RCM [57,58]. When 47 was treated with 10 mol \% of G-HII at $\mathrm{rt}$ in toluene, the seven-membered ring product $\mathbf{4 8}$ was obtained, whereas at $110^{\circ} \mathrm{C}$ the isomerized compound 49 was isolated (Scheme 19). It should be noted that in all cases, tetrasubstituted pyrimidines were involved in the RCM and the substituents in the $\alpha$ position of the $N$-heteroatoms might have a role in the success of these reactions by causing steric hindrance around the nitrogen and thus preventing the catalyst deactivation.

In 2013, Moss generalized the method to the formation of azepines fused with a variety of heteroaromatics including pyrimidines, pyridines, thiazoles and pyrrazoles [59]. Interestingly, most of the heteroaryls possess a chlorine substituent but no explanation was given concerning its putative role in the success of the RCM (Scheme 20). It should be proposed that the chlorine atoms decrease the basicity of $N$-heteromatics through electron-withdrawing effects and thus reduce the catalyst deactivation. In addition, as chlorine atoms are present in the $\alpha$ position regarding to the nitrogen atom, steric effects cannot be neglected.<smiles>Cc1nc(-c2ccccc2)nc2c1CC=CCN2C(CC(C)C)C(=O)NC1CCCCC1</smiles>

48<smiles>C=CCc1c(C)nc(-c2ccccc2)nc1N(CC=C)C(CC(C)C)C(=O)NC1CCCCC1</smiles>

47

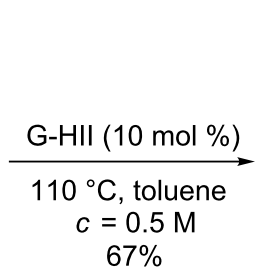

$67 \%$<smiles>CC(C)CC(C(=O)NC1CCCCC1)N1CCC=Cc2c1nc(-c1ccccc1)nc2[N+](=O)[O-]</smiles>

49 
<smiles>C=CCc1c([N+](=O)[O-])cc(Cl)nc1Cl</smiles>

50<smiles>C=CCc1ccc(Cl)nc1NC(=O)[O-]</smiles>

52<smiles>C=CCc1sc(Cl)nc1N(CC=C)C(=O)O</smiles>

54

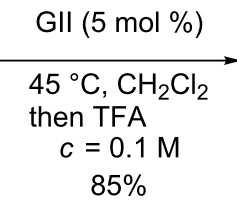

GII (5 mol \%)

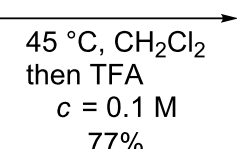

GII (5 mol \%)

$70{ }^{\circ} \mathrm{C}$, toluene $c=0.1 \mathrm{M}$

$81 \%$<smiles>Clc1cc2c(c(Cl)n1)CC=CCN2</smiles>

51<smiles>Clc1ccc2c(n1)NCC=CC2</smiles>

53<smiles></smiles>

55

Scheme 20: RCM involving alkenes containing various $N$-heteroaromatics.

Another example of RCM involving alkenes that possess 2-chloropyridines was reported to produce dihydroisoquinoline 57 from 2,6-dichloro-3,4-diallylpyridine (56) [60]. The addition of benzoquinone prevented the isomerization of the double bond and it may be suspected that the presence of the two chlorine atoms significantly decreased the basicity of the pyridine (Scheme 21).<smiles>C=CCc1cc(Cl)nc(Cl)c1CC=C</smiles>

56

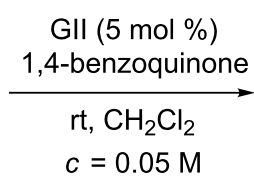

$75 \%$

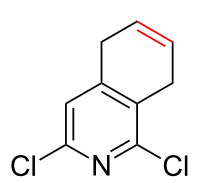

57
Scheme 21: Synthesis of dihydroisoquinoline using a RCM.

Tricyclic compound $\mathbf{5 9}$ was prepared by a RCM of diene $\mathbf{5 8}$ that incorporates a quinoline moiety [61]. In this case, a phenyl group was present at $\mathrm{C} 2$ and may be responsible for avoiding the nitrogen-induced deactivation of the catalyst by both electronic and steric effects (Scheme 22).
Macrocycles embedding $N$-heteroaromatics have been prepared using a RCM reaction. Shirbate et al. used a RCM to synthesize normuscopyridine and analogues [62]. When a diastereomeric mixture of 2,6-disubstituted pyridine $\mathbf{6 0}$ was treated with GI, the expected macrocycle 61 was obtained (51\%) together with the dimeric cyclophane 62 (20\%). The authors explained that the sulfone moieties facilitated the RCM by steering the alkenyl chains into a favorable conformation, but it also may be hypothesized that the steric hindrance caused by the sulfone groups might reduce the ability of the nitrogen atom in deactivating the ruthenium catalyst. A desulfonylation followed by a hydrogenation of the double bond afforded normuscopyridine (Scheme 23).

Other syntheses of cyclophanes using RCM were reported in the literature. Macrocycle 64 was obtained from diene 63 in good yield in the presence of the GI catalyst under diluted conditions [63]. Once again, the presence of the two alkoxy substituents at the $\mathrm{C} 2$ position of the pyridyl rings might not be innocent in the success of the RCM and steric hindrance may be invoked to explain the absence of catalyst deactivation (Scheme 24).<smiles>C=CCc1c(-c2ccccc2)nc2ccccc2c1CC=C</smiles>

58

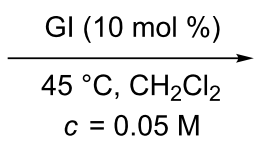

$90 \%$<smiles>C1=CCc2c(c(-c3ccccc3)nc3ccccc23)C1</smiles>

59 


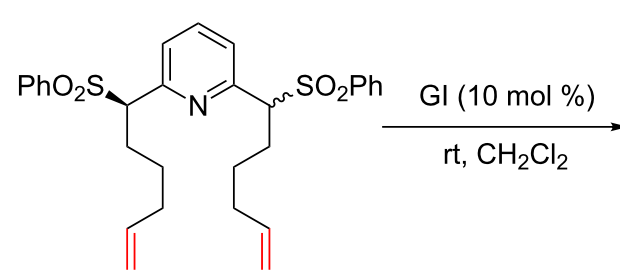

60

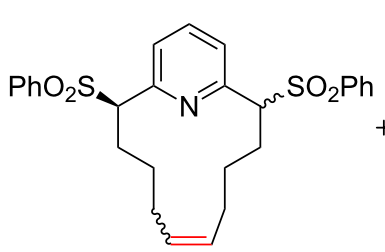

61

$(51 \%)$

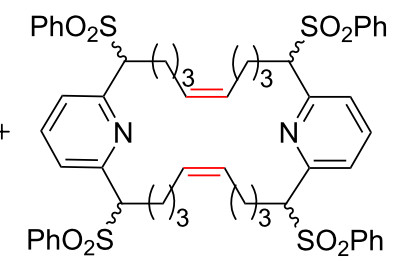

62

$(20 \%)$<smiles>C=CCCCCCCCCCc1cc[14c](I=C)cn1</smiles>

normuscopyridine

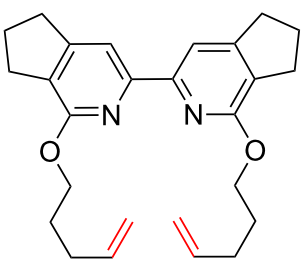

63

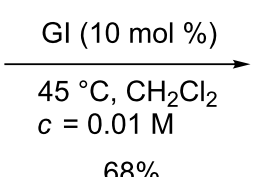

$68 \%$

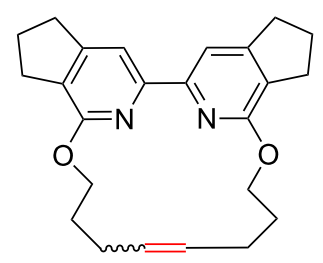

64

$(E / Z=4: 1)$

Scheme 24: Synthesis of macrocycle 64.

Similarly, 15- to 18-membered ring macrocycles that incorporate an imidazole group were synthesized using a RCM of the corresponding dienes using GII as the catalyst (Scheme 25) [6466].

By examining all these examples of successful RCM involving alkenes containing $N$-heteroaromatics, it seems that decreasing their Brønsted basicity and/or their nucleophilicity through the introduction of suitable electron-withdrawing and/or bulky substituents may prevent the catalyst deactivation thus allowing the metathesis to proceed.

\section{Cross-metathesis}

Examples of CM that involve an alkene containing $N$-heteroaromatics as one of the two partners are scarce [67-70]. In 2004, Zhang and co-workers planned to use a cross-metathesis
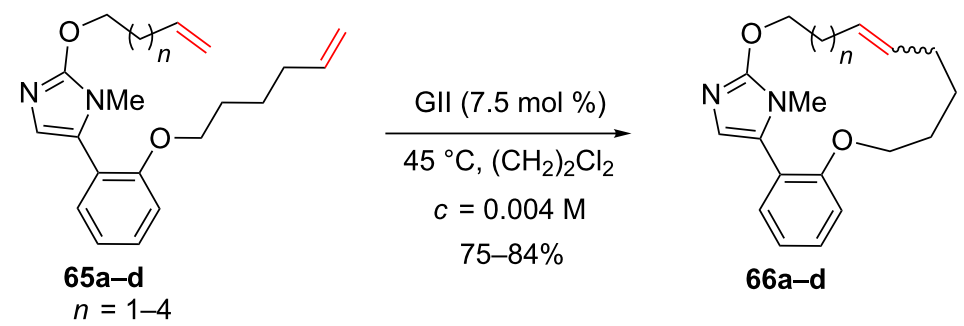

Scheme 25: Synthesis of macrocycles possessing an imidazole group. 
between $\mathbf{6 7}$ and vinylquinoline $\mathbf{6 8}$ in order to synthesize ABT-773, an analogue of erythromycin possessing a 6-O-propenylquinoline side chain (Scheme 26) [71-74].

The cross-metathesis between $\mathbf{6 7}$ and vinylquinoline $\mathbf{6 8}$ in the presence of the GI catalyst was investigated and the authors showed that the success of the reaction required either long reaction time (168 h) (Table 4, entry 1$)$, high catalyst loading (25 mol \%) (Table 4, entry 2) or an excess of the precious macrolide ( 3 equiv) (Table 4 , entry 3 ). Using an excess of the vinylquinoline 68 ( 5 equiv) was detrimental to the reaction as 69 was isolated in a poor yield of $23 \%$. This observation might be explained by the deactivation of the GI catalyst caused by the quinoline (Table 4, entry 4).
In their retrosynthesis of haminol A, O'Neil et al. initially envisionned to access the trienic compound using a crossmetathesis/benzoyloxysulfone elimination sequence. The CM would involve 3-vinylpyridine $\mathbf{7 0}$ as one of the two partners (Scheme 27) [75].

As the 3-vinylpyridine $\mathbf{7 0}$ was far less precious compared to alkene 71, it was used in excess in order to favor the CM product over homodimers. However, no reaction occurred neither with GI nor with GII catalysts and the starting materials were recovered. This absence of reactivity was attributed to the deactivation of the ruthenium catalyst due to the excess of pyridine in the reaction medium. Indeed, a successful metathesis was performed between 3-vinylpyridine (70) and a large excess of

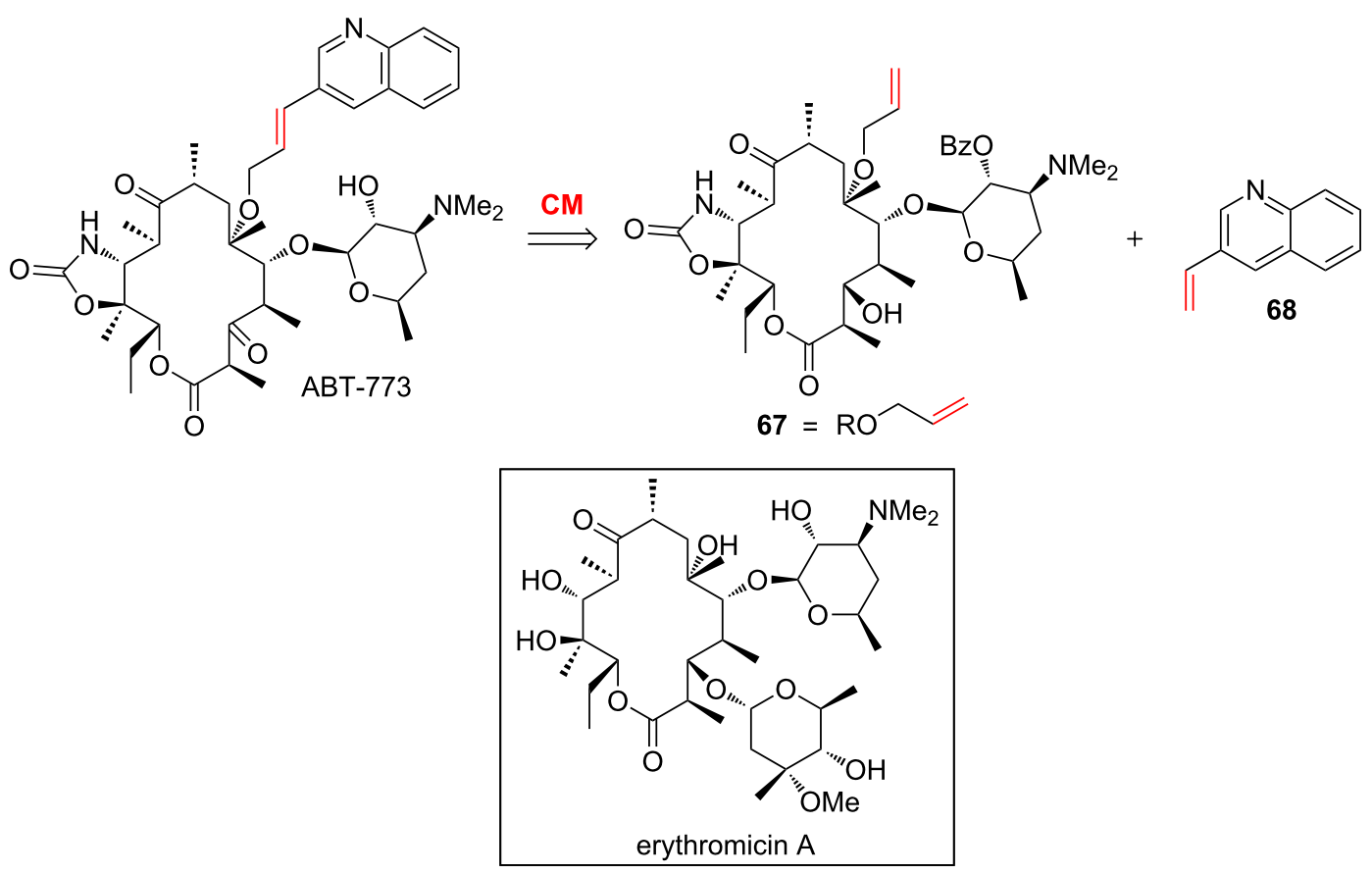

Scheme 26: Retrosynthesis of an analogue of erythromycin.

Table 4: CM between vinylquinoline and an O-allyl-protected erythronolide derivative.<smiles>[R]OCC=C[CH2+]</smiles>

67
68<smiles>[R]C/C=C/c1cnc2ccccc2c1</smiles>

69

\begin{tabular}{llllll}
\hline Entry & $\mathbf{6 7}$ (equiv) & $\mathbf{6 8}$ (equiv) & Time (h) & Gl (mol \%) \\
\hline 1 & 1 & 2 & 168 & 10 & $71 \%$ \\
2 & 1 & 2 & 65 & 25 & $75 \%$ \\
3 & 3 & 1 & 65 & 10 & $79 \%$ \\
4 & 1 & 5 & 20 & 10 & $23 \%$
\end{tabular}


<smiles>CC(O)C/C=C/C=C/C=C/c1cccnc1</smiles>

haminol $\mathrm{A}$

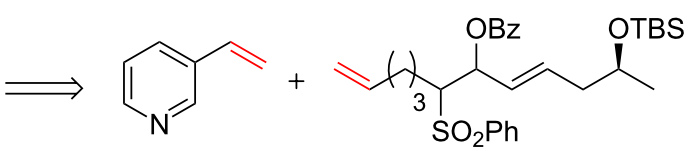

70
71

Scheme 27: Retrosynthesis of haminol A.

cis-1,4-diacetoxy-2-butene (73, 10 equiv) delivering the corresponding alkene $\mathbf{7 4}$ in $85 \%$ yield (Scheme 28 ).

As the use of a large excess of the functionalized alkene partner 71 was not attractive, the authors revised their synthetic strategy and finally installed the triene moiety by means of a double benzoyloxysulfone elimination applied to compound $\mathbf{7 6}$ which was prepared from aldehyde 77 (Scheme 29).

Aldehyde $\mathbf{7 7}$ was assembled by a CM between alkene $\mathbf{7 8}$ and crotonaldehyde (79). It should be noted that in this case, the CM proceeded smoothly delivering the desired olefin in $78 \%$ yield despite the presence of the pyridine. Worthy of note, the amount of crotonaldehyde added in the reaction was not given in the article (Scheme 30).

Based on NMR studies, the formation of an inactive ruthenium pyridylalkylidene $\mathbf{8 0}$ resulting from a reaction between GII and the vinylpyridine in excess was hypothesized to be the cause of the deactivation of the catalyst (Scheme 31). The use of a large excess of the alkene partner such as cis-1,4-diacetoxy-2-butene may statistically prevent the formation of $\mathbf{8 0}$ thus allowing the CM to occur.

In 2010, Harding et al. attempted to use reversible aqueous metathesis for the construction of a dynamic combinatorial

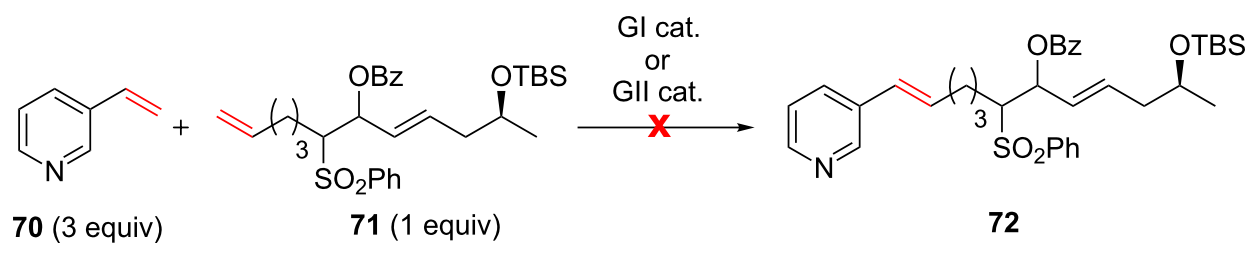<smiles>C=Cc1cccnc1</smiles><smiles>CC(=O)OC/C=C\COC(C)=O</smiles>

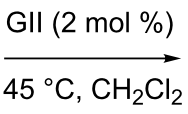

70 (1 equiv)

73 (10 equiv)

$85 \%$<smiles>CC(=O)OC/C=C/c1cccnc1</smiles>

74

Scheme 28: CM involving 3-vinylpyridine 70 with 71 and vinylpyridine 70 with 73 .<smiles>C#CC(C/C=C/C=C/C=C/c1cccnc1)O[SbH3]</smiles>

75

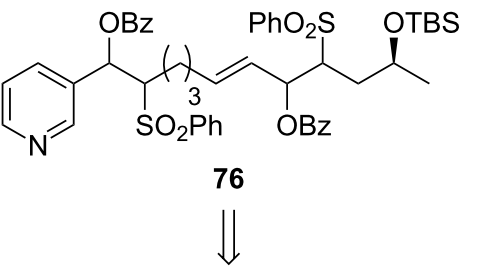<smiles>CC(C)(C)OC(c1cccnc1)C(C(C)(C)c1ccccc1)S(=O)(=O)Oc1ccccc1</smiles>

77 
<smiles>C=CC(C)C(C(=O)OCc1ccccc1)C(c1cccnc1)S(=O)(=O)c1ccccc1</smiles>

78
79<smiles>CC(C=CC=O)C(C(OC(C)(C)C)C(C)(C)C)S(=O)(=O)c1ccccc1</smiles>

77

Scheme 30: CM between 78 and crotonaldehyde.<smiles></smiles>

GII
$+$<smiles>C=Cc1cccnc1</smiles>

70<smiles></smiles>

80

(inactive in $\mathrm{CM}$ )

library aimed at identifying DNA ligands [76]. Toward that goal, biologically relevant conditions were selected (rt, $t-\mathrm{BuOH} /$ $\mathrm{H}_{2} \mathrm{O}$ ) and $\mathrm{CM}$ involving allyl sulfides that contain functional groups commonly found in DNA-intercalators and $\mathrm{N}$-heteroaromatics were investigated. When a quinoline was present on the allylic sulfide, allylic alcohol was found to be the unique suitable partner among the tested olefins. In addition, 20 equiv of allylic alcohol were required and the CM product was obtained in a moderate $53 \%$ yield. Cross-metathesis of $\mathbf{8 1}$ with amide $\mathbf{8 3}$ or alkene $\mathbf{8 5}$ gave no conversion (Scheme 32 ).

In the presence of a quinoxaline moiety on the allyl sulfide, the $\mathrm{CM}$ reaction with allylic alcohol delivered $\mathbf{8 8}$ in a low $31 \%$ yield and when an alkene containing a phenanthroline was used, no reaction occurred. By the light of the previously reported observations, these results could be imputed to the deactivation<smiles>C=CCSCc1ccc2ccccc2n1</smiles>

81
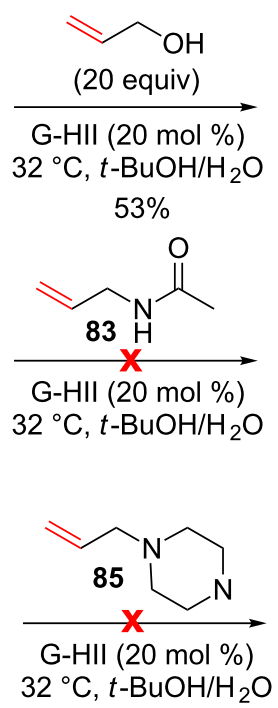<smiles>O=C(O)CSCc1ccc2ccccc2n1</smiles><smiles>CC(=O)NC/C=C/CSCc1ccc2ccccc2n1</smiles>

84<smiles></smiles> 
<smiles>C=CCSCc1cnc2ccccc2n1</smiles>

87<smiles>C=CCSCc1cc2cccnc2c2ncccc12</smiles>

89

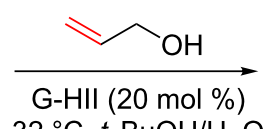

$32{ }^{\circ} \mathrm{C}, t-\mathrm{BuOH} / \mathrm{H}_{2} \mathrm{O}$

$31 \%$

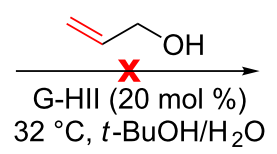

$32{ }^{\circ} \mathrm{C}, t-\mathrm{BuOH} / \mathrm{H}_{2} \mathrm{O}$<smiles>OC/C=C/CSCc1cnc2ccccc2n1</smiles>

88<smiles>OC/C=C/CSCc1cc2cccnc2c2ncccc12</smiles>

90

Scheme 33: CM involving allylic sulfide possessing a quinoxaline or a phenanthroline.

of the ruthenium catalyst caused by $N$-heteroaromatics (Scheme 33).

One of the rare successful example of CM involving alkene containing a pyridine moiety was reported by Sarpong et al. in their total synthesis of $( \pm)$-lyconadin A [77]. Alkene 91 was coupled with ethyl acrylate (5 equiv) using a catalytic amount of the G-HII catalyst to give $\mathbf{9 2}$ with a very good yield of $88 \%$ (Scheme 34).

It should be noted that, in this case, the pyridyl ring is substituted by a methoxy group and a bromide and these substituents might be non-innocent in the success of the CM. The presence of 2 substituents at C2 and C6 may cause steric hindrance and the bromine atom at $\mathrm{C} 3$ may decrease the basicity of the nitrogen atom through inductive effect. Indeed, in a recent study published by our group, it was demonstrated that successful $\mathrm{CM}$ involving alkenes that contain $N$-heteroaromatics could be performed by the introduction of a suitable electron-withdrawing group on the $N$-heteroaryl ring [78]. When olefin 93, bearing a pyridine without any substituent at $\mathrm{C} 2$ or $\mathrm{C} 6$, was treated with methyl acrylate in the presence of G-HII catalyst no reaction took place and the starting material was fully recovered. By contrast, the presence of a chlorine substituent at $\mathrm{C} 2$ on the pyridyl ring restored the reactivity of the olefin in the $\mathrm{CM}$ as the expected product was isolated in $84 \%$ yield (Scheme 35). We hypothesized that the presence of the chlorine atom modulates the Lewis and/or Brønsted basicity of the nitrogen atom, thus preventing the deactivation of the ruthenium catalyst (vide infra).

Various substituents on the pyridyl ring such as halides, trifluoromethyl or triflate groups were found to be suitable basicity modulators and the alkenes containing the corresponding disubstituted pyridines were efficiently coupled to methyl acrylate by utilizing a $\mathrm{CM}$ reaction. In addition, steric hindrance next to the nitrogen atom could also play a role by decreasing the nucleophilicity of the nitrogen as attested by the formation of alkene 98f in a moderate $52 \%$ yield (Scheme 36 ).

This strategy was applied to the formation of a broad variety of disubstituted olefins containing $N$-heteroaromatic moieties such as pyridines, pyrimidines, imidazoles and pyrazoles (Scheme 37).

From the selected examples discussed above, we tried to delineate some trends regarding to the use of alkenes possessing $N$-heteroaromatics in RCM and CM. In RCM, GI and GII are<smiles>C=CCC1=C(Cc2nc(OC)ccc2Br)CCCC1=O</smiles>

Scheme 34: CM between an acrylate and a 2-methoxy-5-bromo pyridine. 
<smiles>COC(=O)C=C=CCC(O)c1cccnc1</smiles><smiles>CCCCC(C)(C)OC(=O)C=C=CCC(O)c1cccnc1Cl</smiles>

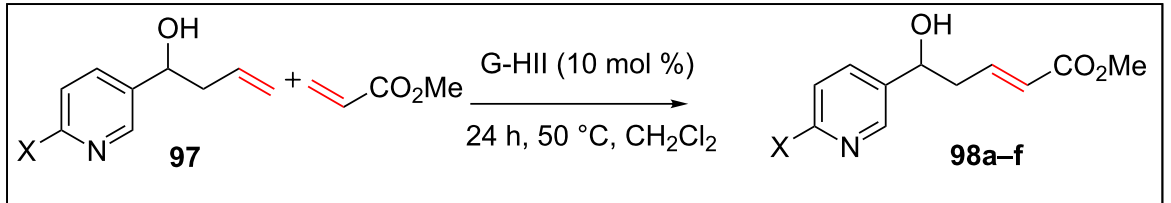<smiles>CC(=O)C=CCC(O)c1ccc(Cl)nc1</smiles><smiles>CC(=O)C=CCC(O)c1ccc(Br)nc1</smiles><smiles>CC(=O)C=CCC(O)c1ccc(F)nc1</smiles><smiles>COC(=O)C=CCC(O)c1ccc(C(F)(F)F)nc1</smiles><smiles>COC(=O)C=CCC(O)c1ccc(C(C)(C)C)nc1</smiles>

Scheme 36: Variation of the substituent on the pyridine ring

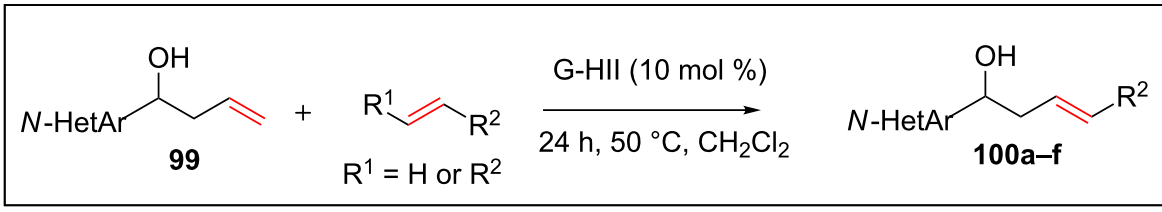<smiles>CC(=O)OC/C=C/CC(O)c1cccnc1Cl</smiles><smiles>CCO[SiH2]C=CCC(O)c1cccnc1Cl</smiles><smiles>CC(=O)/C=C/CC(O)c1cccnc1Cl</smiles><smiles>COC(=O)C=CCC(O)c1c(Cl)ncnc1Cl</smiles><smiles>COC(=O)C=CCC(O)c1cnc(Cl)[nH]1</smiles><smiles>COC(=O)C=CCC(O)c1cnn(C)c1Cl</smiles> 
usually preferred and diluted conditions are recommended to avoid dimerization. The most studied strategy allowing the use of olefins bearing $N$-heteroaromatics is the formation of the $\mathrm{N}$-heteroaromatic salt prior to metathesis. The salt can be either isolated before metathesis or formed in situ using acidic additives. Alternatively, introduction of bulky and/or electron-withdrawing substituents on the $N$-heteroaromatic ring allows the metathesis to proceed by preventing nitrogen-induced catalyst deactivation. However, no general study dealing with the influence of the $N$-heteroaromatic substituents on the outcome of the RCM has been led so far. In CM, G-HII may be considered as the most potent catalyst even if some examples involving GII catalyst are described in the literature. Two strategies can be adopted to use olefins possessing $N$-heteroaromatics as one of the partner. When the second partner is non-expensive, it can be introduced in large excess thus avoiding the $N$-heteroaromatic induced catalyst deactivation. As an alternative, bulky and/or electron-withdrawing substituents can be introduced on the $\mathrm{N}$-heteroaromatic to reduce the basicity of the nitrogen atom and thus the deactivation. This strategy appears as the most promising especially as a simple chlorine substituent is sufficient to allow the metathesis to proceed (Table 5).

\section{Conclusion}

$\mathrm{N}$-Heteroaromatics are known to have a deleterious impact on metathesis by inducing ruthenium catalysts deactivation. Based on NMR and kinetic mechanistic studies, Lewis and/or Brønsted basicity of amines appeared to be responsible for the degradation of the catalyst. The most common solution proposed to circumvent the problem is the protonation of the nitrogen atom of $N$-heteroaromatics prior to the metathesis that can then be carried out using the corresponding salts. By close examination of the successful metatheses involving alkenes that possess non-protonated $N$-heteroaromatics, the presence of electron-withdrawing and/or bulky substituents on the heteroarene was noticed to be beneficial. These substituents can allow a fine tuning of the basicity and/or nucleophilicity of the nitrogen thus preventing the catalyst deactivation. By unravelling catalyst deactivation pathways, mechanistic investigations could help to extend the scope of the metathesis reactions to alkenes containing $N$-heteroaromatics, thus overcoming one major barrier to the widespread use of metathesis, particularly for industrial purposes.

\section{References}

1. Fürstner, A. Alkene Metathesis in Organic Synthesis; Springer: Berlin, 1998.

2. Grubbs, R. H.; Wenzel, A. G.; O'Leary, D. J.; Khosravi, E., Eds. Handbook of Metathesis, 2nd ed.; Wiley-VCH: Weinheim, 2015. doi:10.1002/9783527674107

3. Grela, K. Olefin Metathesis. Theory and Practise; Wiley, 2014. doi:10.1002/9781118711613

4. Fürstner, A. Angew. Chem., Int. Ed. 2000, 39, 3012. doi:10.1002/1521-3773(20000901)39:17<3012::AID-ANIE3012>3.0.CO ;2-G

5. Connon, S. J.; Blechert, S. Angew. Chem., Int. Ed. 2003, 42, 1900. doi:10.1002/anie.200200556

6. Fürstner, A. Science 2013, 341, 1229713. doi:10.1126/science.1229713

7. Saito, A.; Hanzawa, Y. Metathesis Reactions in Drug and Natural Products. Stereoselective Synthesis of Drugs and Natural Products; Wiley, 2013.

8. Cossy, J.; Arseniyadis, S.; Meyer, C. Metathesis in Natural Product Synthesis: Strategies, Substrates and Catalysts; Wiley-VCH: Weinheim, 2010. doi:10.1002/9783527629626.fmatter

9. Cossy, J.; Arseniyadis, S., Eds. Modern Tools for the Synthesis of Complex Bioactive Molecules; Wiley, 2012. doi:10.1002/9781118342886

10. Nicolaou, K. C.; Bulger, P. G.; Sarlah, D. Angew. Chem., Int. Ed. 2005, 44, 4490. doi:10.1002/anie.200500369

11. Dassonneville, B.; Delaude, L.; Demonceau, A.; Dragutan, I.; Dragutan, V.; Etsè, K. S.; Hans, M. Curr. Org. Chem. 2013, 17, 2609. doi:10.2174/1385272811317220006

12. Bielawski, C. W.; Grubbs, R. H. Prog. Polym. Sci. 2007, 32, 1. doi:10.1016/j.progpolymsci.2006.08.006

13. Nolan, S.; Clavier, H. Chem. Soc. Rev. 2010, 39, 3305. doi:10.1039/b912410c

14. Chatterjee, A. K.; Choi, T.-L.; Sanders, D. P.; Grubbs, R. H. J. Am. Chem. Soc. 2003, 125, 11360. doi:10.1021/ja0214882

15. Hoye, T. R.; Zhao, H. Org. Lett. 1999, 1, 1123. doi:10.1021/ol990947+ 16. Lin, Y. A.; Davis, B. G. Beilstein J. Org. Chem. 2010, 6, 1219. doi:10.3762/bjoc.6.140

17. Yun, J. I.; Kim, H. R.; Kim, S. K.; Kim, D.; Lee, J. Tetrahedron 2012, 68, 1177. doi:10.1016/j.tet.2011.11.064

18. Choi, T.-L.; Chatterjee, A. K.; Grubbs, R. H. Angew. Chem., Int. Ed. 2001, 40, 1277. doi:10.1002/1521-3773(20010401)40:7<1277::AID-ANIE1277>3.0.CO; 2-E

19. Hoveyda, H. R.; Vézina, M. Org. Lett. 2005, 7, 2113. doi:10.1021/ol050387g

20. Donohoe, T. J.; Race, N. J.; Bower, J. F.; Callens, C. K. A. Org. Lett. 2010, 12, 4094. doi:10.1021/ol101681r

21. Compain, P. Adv. Synth. Catal. 2007, 349, 1829. doi:10.1002/adsc. 200700161

Table 5: Metathesis involving alkenes that contain $\mathrm{N}$-heteroaromatics.

\begin{tabular}{llll} 
Metathesis & Cat. & Conditions & Strategies \\
\hline RCM & GI or GII & diluted & $* N$-heteroaromatic salt formation prior to CM \\
CM & G-HII & * Non $N$-heteroaromatic partner in large excess \\
& & * Bulky and/or electron withdrawing substituent on the $N$-heteroaromatic
\end{tabular}


22. Chattopadhyay, S. K.; Karmakar, S.; Biswas, T.; Majumdar, K. C.; Rahaman, H.; Roy, B. Tetrahedron 2007, 63, 3919. doi:10.1016/j.tet.2007.01.063

23. Felpin, F.-X.; Lebreton, J. Eur. J. Org. Chem. 2003, 3693. doi:10.1002/ejoc.200300193

24. Compain, P.; Hazelard, D. Top. Heterocycl. Chem. 2015, 1. doi:10.1007/7081_2014_139

25. Wang, H.; Goodman, S. N.; Dai, Q.; Stockdale, G. W.; Clark, W. M., Jr. Org. Process Res. Dev. 2008, 12, 226. doi:10.1021/op700288p

26. Yee, N. K.; Farina, V.; Houpis, I. N.; Haddad, N.; Frutos, R. P.; Gallou, F.; Wang, X.-J.; Wei, X.; Simpson, R. D.; Feng, X.; Fuchs, V.; Xu, Y.; Tan, J.; Zhang, L.; Xu, J.; Smith-Keenan, L. L.; Vitous, J.; Ridges, M. D.; Spinelli, E. M.; Johnson, M.; Donsbach, K.; Nicola, T.; Brenner, M.; Winter, E.; Kreye, P.; Samstag, W. J. Org. Chem. 2006, 71, 7133. doi:10.1021/jo060285j

27. Nomura, H.; Richards, C. J. Org. Lett. 2009, 11, 2892. doi:10.1021/ol900880w

28. Yoshida, K.; Kawagoe, F.; Hayashi, K.; Horiuchi, S.; Imamoto, T.; Yanagisawa, A. Org. Lett. 2009, 11, 515. doi:10.1021/ol8023117

29. Dragutan, I.; Dragutan, V.; Demonceau, A. RSC Adv. 2012, 2, 719. doi:10.1039/C1RA00910A

30. Fu, G. C.; Nguyen, S. T.; Grubbs, R. H. J. Am. Chem. Soc. 1993, 115, 9856. doi:10.1021/ja00074a085

31. Kirkland, T. A.; Lynn, D. M.; Grubbs, R. H. J. Org. Chem. 1998, 63, 9904. doi:10.1021/jo981678o

32. Woodward, C. P.; Spiccia, N. D.; Jackson, W. R.; Robinson, A. J. Chem. Commun. 2011, 47, 779. doi:10.1039/C0CC03716H

33. Nash, A.; Soheili, A.; Tambar, U. K. Org. Lett. 2013, 15, 4770. doi:10.1021/ol402129h

34. Malik, M.; Witkowski, G.; Ceborska, M.; Jarosz, S. Org. Lett. 2013, 15, 6214. doi:10.1021/ol403063v

35. Cheng, X.; Waters, S. P. Org. Lett. 2010, 12, 205. doi:10.1021/ol902455y

36. Vedrenne, E.; Dupont, H.; Oualef, S.; Elkaïm, L.; Grimaud, L. Synlett 2005, 670. doi:10.1055/s-2005-862375

37. Shafi, S.; Kędziorek, M.; Grela, K. Synlett 2011, 124. doi:10.1055/s-0030-1259083

38. This mini-review is restricted to metathesis involving alkenes containing $\mathrm{N}$-heteroaromatics. Metathesis reactions involving olefins that include primary or secondary amines have been reviewed elsewhere, see [21].

39. Wilson, G. O.; Porter, K. A.; Weissman, H.; White, S. R.; Sottos, N. R.; Moore, J. S. Adv. Synth. Catal. 2009, 351, 1817. doi:10.1002/adsc.200900134

40. Sanford, M. S.; Love, J. A.; Grubbs, R. H. Organometallics 2001, 20, 5314. doi:10.1021/om010599r

41. Bolton, S. L.; Williams, J. E.; Sponsler, M. B. Organometallics 2007, 26, 2485. doi:10.1021/om061098e

42. Bates, J. M.; Lummiss, J. A. M.; Bailey, G. A.; Fogg, D. E. ACS Catal. 2014, 4, 2387. doi:10.1021/cs500539m

43. Lummiss, J. A. M.; McClennan, W. L.; McDonald, R.; Fogg, D. E. Organometallics 2014, 33, 6738. doi:10.1021/om501011y

44. Hong, S. H.; Wenzel, A. G.; Salguero, T. T.; Day, M. W.; Grubbs, R. H. J. Am. Chem. Soc. 2007, 129, 7961. doi:10.1021/ja0713577

45. Lummiss, J. A. M.; Ireland, B. J.; Sommers, J. M.; Fogg, D. E. Chem CatChem 2014, 6, 459. doi:10.1002/cctc.201300861

46. Ireland, B. J.; Dobigny, B.; Fogg, D. E. ACS Catal. 2015, 5, 4690. doi:10.1021/acscatal.5b00813

47. Núñez, A.; Cuadro, A. M.; Alvarez-Builla, J.; Vaquero, J. J. Org. Lett. 2004, 6, 4125. doi:10.1021/ol048177b
48. Núñez, A.; Abarca, B.; Cuadro, A. M.; Alvarez-Builla, J.; Vaquero, J. J. J. Org. Chem. 2009, 74, 4166. doi:10.1021/jo900292b

49. Núñez, A.; Cuadro, A. M.; Alvarez-Builla, J.; Vaquero, J. J. Org. Lett. 2007, 9, 2977. doi:10.1021/ol070773t

50. Núñez, A.; Cuadro, A. M.; Alvarez-Builla, J.; Vaquero, J. J. Chem. Commun. 2006, 2690. doi:10.1039/B602420C

51. Fürstner, A.; Leitner, A. Angew. Chem., Int. Ed. 2003, 42, 308. doi:10.1002/anie.200390103

52. Fürstner, A.; Grabowski, J.; Lehmann, C. W. J. Org. Chem. 1999, 64, 8275. doi:10.1021/jo991021i

53. Chen, Y.; Rasika Dias, H. V.; Lovely, C. J. Tetrahedron Lett. 2003, 44, 1379. doi:10.1016/S0040-4039(02)02864-2

54. Lee, K. L.; Goh, J. B.; Martin, S. F. Tetrahedron Lett. 2001, 42, 1635. doi:10.1016/S0040-4039(01)00002-8

55. Baker, S. R.; Cases, M.; Keenan, M.; Lewis, R. A.; Tan, P. Tetrahedron Lett. 2003, 44, 2995. doi:10.1016/S0040-4039(03)00389-7

56. van Otterlo, W. A.; Morgans, G. L.; Khanye, S. D.; Aderibigbe, B. A. A.; Michael, J. P.; Billing, D. G. Tetrahedron Lett. 2004, 45, 9171. doi:10.1016/j.tetlet.2004.10.108

57. El Kaïm, L.; Grimaud, L.; Oble, J. J. Org. Chem. 2007, 72, 5835. doi:10.1021/jo070706c

58. Majumdar, K. C.; Mondal, S.; Ghosh, D. Synthesis 2010, 1176. doi:10.1055/s-0029-1219228

59. Moss, T. A. Tetrahedron Lett. 2013, 54, 993. doi:10.1016/j.tetlet.2012.12.042

60. van den Hoogenband, A.; den Hartog, J. A. J.; Faber-Hilhorst, N.; Lange, J. H. M.; Terpstra, J. W. Tetrahedron Lett. 2009, 50, 5040. doi:10.1016/j.tetlet.2009.06.101

61. Luo, J.; Huo, Z.; Fu, J.; Jin, F.; Yamamoto, Y. Org. Biomol. Chem. 2015, 13, 3227. doi:10.1039/C4OB02567A

62. Kotha, S.; Waghule, G. T.; Shirbate, M. E. Eur. J. Org. Chem. 2014, 984. doi:10.1002/ejoc.201301493

63. Branowska, D.; Rykowski, A. Tetrahedron 2005, 61, 10713. doi:10.1016/j.tet.2005.08.081

64. Van Den Berge, E.; Pospíšil, J.; Trieu-Van, T.; Collard, L.; Robiette, R. Eur. J. Org. Chem. 2011, 6649. doi:10.1002/ejoc.201100805

65. Halland, N.; Blum, H.; Buning, C.; Kohlmann, M.; Lindenschmidt, A. ACS Med. Chem. Lett. 2014, 5, 193. doi:10.1021/ml4004556 See for other syntheses of macrocyles possessing $N$-heteroaromatics using RCM

66. Rudd, M. T.; Butcher, J. W.; Nguyen, K. T.; Mclntyre, C. J.; Romano, J. J.; Gilbert, K. F.; Bush, K. J.; Liverton, N. J.; Holloway, M. K.; Harper, S.; Ferrara, M.; DiFilippo, M.; Summa, V.; Swestock, J.; Fritzen, J.; Carroll, S. S.; Burlein, C.; DiMuzio, J. M.; Gates, A.; Graham, D. J.; Huang, Q.; McClain, S.; McHale, C.; Stahlhut, M. W.; Black, S.; Chase, R.; Soriano, A.; Fandozzi, C. M.; Taylor, A.; Trainor, N.; Olsen, D. B.; Coleman, P. J.; Ludmerer, S. W.; McCauley, J. A. ChemMedChem 2015, 10, 727. doi:10.1002/cmdc.201402558

67. Luo, G.; Dubowchik, G. M.; Macor, J. E.; Chen, L. CGRP Receptors Antagonists. PCT International Application WO 2012154354, Nov 15, 2012. And [68-70]. See for some other examples of $\mathrm{CM}$ involving alkenes containing $\mathrm{N}$-heteroaromatics, that are not discussed in the review.

68. Corte, J. R.; Fang, T.; Decicco, C. P.; Pinto, D. J. P.; Rossi, K. A.; Hu, Z.; Jeon, Y.; Quan, M. L.; Smallheer, J. M.; Wang, Y.; Yang, W. Macrocycles as Factor Xia Inhibitors. PCT International Application WO 2011100401, Aug 18, 2011. 
69. Defossa, E.; Goerlitzer, J.; Klabunde, T.; Drosou, V.; Stengelin, S.; Haschke, G.; Herling, A.; Bartoschek, S. 4,5-Diphenyl-pyrimidinyl-oxy or -mercapto substituted carboxylic acids, methods for the production and use thereof as medicaments. PCT International Application WO 2007131619, Nov 22, 2007.

70. Ksander, G. M.; Meredith, E.; Monovich, L. G.; Papillon, J.; Firooznia, F.; Hu, Q.-Y. Condensed Imidazolo Derivatives for the Inhibition of Aldosterone and Aromatase. PCT International Application WO 2007024945, March 1, 2007

71. Hsu, M. C.; Junia, A. J.; Haight, A. R.; Zhang, W. J. Org. Chem. 2004, 69, 3907. doi:10.1021/jo049737n

72. Or, Y. S.; Ma, Z.; Clark, R. F.; Chu, D. T.; Plattner, J. J.; Griesgaber, G. 6-O-Substituted Ketolides Having Antibacterial Activity. U.S. Patent 5,866,549, Feb 2, 1999.

And $[73,74]$. See for ABT-773 which was an anti-infective candidate developed at Abbott Laboratories.

73. Or, Y. S.; Ma, Z.; Clark, R. F.; Chu, D. T.; Plattner, J. J.; Griesgaber, G. 6-O-Substituted Antibacterial Erythromycin Ketolides and Methods of Making. U.S. Patent 6,028,181, Feb 22, 2000.

74. Or, Y. S.; Ma, Z.; Clark, R. F.; Chu, D. T.; Plattner, J. J.; Griesgaber, G. 6-O-Substituted Antibacterial Erythromycin Ketolides and Methods of Making. U.S. Patent 6,075,133, June 16, 2000.

75. Storvick, J. M.; Ankoudinova, E.; King, B. R.; Van Epps, H.; O'Neil, G. W. Tetrahedron Lett. 2011, 52, 5858. doi:10.1016/j.tetlet.2011.08.153

76. Hunter, L.; Condie, G. C.; Harding, M. M. Tetrahedron Lett. 2010, 51, 5064. doi:10.1016/j.tetlet.2010.07.105

77. Bisai, A.; West, S. P.; Sarpong, R. J. Am. Chem. Soc. 2008, 130, 7222. doi:10.1021/ja8028069

78. Lafaye, K.; Nicolas, L.; Guérinot, A.; Reymond, S.; Cossy, J. Org. Lett. 2014, 16, 4972. doi:10.1021/ol502016h

\section{License and Terms}

This is an Open Access article under the terms of the Creative Commons Attribution License (http://creativecommons.org/licenses/by/2.0), which permits unrestricted use, distribution, and reproduction in any medium, provided the original work is properly cited.

The license is subject to the Beilstein Journal of Organic Chemistry terms and conditions:

(http://www.beilstein-journals.org/bjoc)

The definitive version of this article is the electronic one which can be found at: doi:10.3762/bjoc. 11.241 